\title{
Availability of physical environments and incentives for physical activity in industry companies, Pelotas, Brazil
}

\author{
Disponibilidade de espaços físicos e \\ incentivos à prática de atividades físicas \\ nas indústrias de Pelotas, RS - Brasil
}

Rev Bras Ativ Fis Saúde p. 226-235

DOI:

http://dx.doi.org/10.12820/rbafs.v.18n2p226

1 Programa de Pós-Graduação em

Epidemiologia, Universidade Federal de Pelotas, RS, Brasil.

2 Programa de Pós-Graduação em Educação Física, Universidade Federal de Pelotas,

Pelotas, RS, Brasil.

Virgílio V. Ramires ${ }^{1}$

Airton J. Rombaldi ${ }^{2}$

Grégore I. Mielke ${ }^{1}$

Marlos R. Domingues ${ }^{2}$

Pedro C. Hallal ${ }^{1,2}$

\begin{abstract}
Evidence shows that physically active individuals have lower risk of developing chronic diseases. Despite that, the rate of physical inactivity is high. Difficult access and lack of time are mostly reported as barriers to engaging in physical activity. The workplace is a key setting for physical activity promotion among employees. This study aimed to describe the physical environments and incentives for non-occupational physical activities offered to employees of local industry companies in the city of Pelotas, southern Brazil. A cross-sectional study was conducted with a sample drawn from the Pelotas Center for Businesses (CIPEL) and the Brazilian Special Guides Publisher (EBGE) databases. Companies with more than 20 employees were eligible to participate in the study. The final sample consisted of 81 companies and information was collected through a questionnaire applied to the participating company's business representative. It was found that $12.4 \%$ of the companies had physical environments for physical activity at the workplace, $9.9 \%$ had spaces for indoor sports, $91.4 \%$ had showering facilities and locker rooms, $12.4 \%$ offered health club discounts and $16.0 \%$ subsidized memberships to health clubs and gyms. Participation in employee team sports was reported in $37.0 \%$ of the companies; it was the most common physical activity especially among male employees. In conclusion, local Pelotas companies did not offer their employees adequate spaces for non-occupational physical activity. However, the availability of physical environments such as showering facilities and locker rooms opens up great opportunities for active commuting to work.
\end{abstract}

\section{Keywords}

Motor activity; Industry; Workers; Environment; Epidemiology.

\section{Resumo}

Evidências apontam que praticantes de atividades físicas apresentam menores riscos de desenvolver doenças crônicas. Apesar disso, as proporções de inatividade física são elevadas, sendo que a dificuldade de acesso e tempo são frequentemente referidos como barreiras para prática de atividades físicas. Assim, os locais de trabalho são importantes para promover o aumento dos niveis de atividades físicas dos trabalhadores. Este estudo descreve os espaços físicos e incentivos oferecidos aos trabalhadores das empresas da indústria do município de Pelotas, RS, para à prática de atividades físicas não ocupacionais. Trata-se de um estudo transversal, sendo a amostra obtida dos bancos de dados do Centro das Induistrias de Pelotas e da Editora Brasileira de Guias Especiais. Empresas com mais de 20 trabalhadores foram incluidas na amostra e as informaçôes foram obtidas por meio de questionário aplicado a um representante das empresas. A amostra foi composta por 81 empresas, das quais, 12,4\% possuíam espaço para prática de atividades físicas dentro da empresa, 9,9\% dispunham de quadras esportivas, 91,4\% tinham vestiários com chuveiros, 12,4\% mantinham convênios e 16,0\% subsidiavam atividades físicas em outros locais, como clubes e academias. A prática de esportes coletivos, relatada em 37,0\% das empresas, foi a atividade mais comumente praticada entre trabalhadores do sexo masculino. Concluiu-se que as empresas da indústria de Pelotas, $R S$ não apresentaram espaços físicos adequados para a prática de atividades físicas não ocupacionais. Entretanto, a presença de algumas condiçôes como a disponibilidade de vestiários com chuveiros representa uma importante oportunidade para promover o deslocamento ativo.
Palavras-chave

Atividade motora; Indústria; Trabalhadores; Ambiente; Epidemiologia. 


\section{INTRODUCTION}

Evidence shows that individuals engaging in physical activities have lower risk of developing coronary heart disease, diabetes, arterial hypertension, some cancers, obesity, mental disorders and musculoskeletal diseases. ${ }^{1}$ Despite strong evidence of the health benefits of physical activity, a recent review study including data from more than 100 countries found that $31.1 \%$ of adults over 15 are physically inactive. ${ }^{2}$ A national survey of industry workers in Brazil carried out in 2006-2009 showed that $45.4 \%$ of workers did not engage in leisure-time physical activity. ${ }^{3}$ The prevalence of leisure-time physical inactivity in the State of Rio Grande do Sul, southern Brazil, was 45.6\%. ${ }^{4}$

The most frequently reported barriers to physical activity are lack of time, ${ }^{5,6}$ overwork, fatigue $\mathrm{e}^{7}$ and difficult access to adequate spaces/facilities. ${ }^{5}$ The workplace physical characteristics and availability of spaces/facilities and incentives for physical activity can strongly affect employees' choices and promote physical activity. ${ }^{8,9}$

Review studies have shown that interventions at individual, group, organization and environment levels to promote workplace physical activity have positive effects among employees including increased levels of physical activity, reduction of musculoskeletal disorders, chronic disease prevention, reduction of stress and absenteeism, increased workplace satisfaction, lower leave of absence rates, lower health care costs and increased productivity. ${ }^{10}$ However, few studies - all conducted in high-income countries - have focused on the characteristics of workplace environment and adaptations to promote physical activity. ${ }^{11-16}$

The workplace is a setting where employees spend most of their day. ${ }^{17}$ It is thus crucial to investigate whether workplace environment characteristics can promote non-occupational physical activities and an active lifestyle. In the light of that, the present study aimed to describe the physical environments and incentives for non-occupational physical activity local industry companies offer to their employees.

\section{METHODS}

\section{Study design and sample}

An observational cross-sectional study was conducted. The sample was drawn from the Pelotas Center for Businesses (CIPEL) and the Brazilian Special Guides Publisher (EBGE) databases. ${ }^{18}$ Companies with 20 or more employees were eligible to participate in the study.

\section{Study instrument}

A questionnaire was developed to collect information on physical infrastructure, fitness equipment available, social environment (e.g., staff associations, occupational safety and health committees [OSHC]) and incentives for physical activities such as health club discounts and subsidized memberships to health clubs and gyms. The study questionnaire was developed based on adapted instruments administered in similar international studies. ${ }^{12,15,16}$ It consisted of 59 open-ended and closed-ended questions (yes or no; multiple choice) divided into six blocks: information regarding demographic characteristics of employees (eight questions); physical environments (10 questions); workplace physical activity programs (nine questions, two of them on advertisement strategies); physical activity programs offered outside the workplace (discounts and subsidized memberships and employ- 
ee sports teams) (12 questions, two of them on advertisement strategies); health club discounts (six questions, one on advertisement strategies); and availability of fitness equipment (14 questions). A pilot study was carried out in a sample of employees from two companies in the city of Bagé, $200 \mathrm{~km}$ from Pelotas, to assess the instrument for its applicability and clarity and reliability of responses.

\section{Interviewers}

The group of interviewers consisted of 10 students of Physical Education from Universidade Federal de Pelotas. They received eight hours of training in interviewing and instrument administration. An instrument administration guide was provided to help clarify any questions during the interview. Training activities included questionnaire presentation, explanation of questionnaire questions and interview simulation.

\section{Study logistics}

Eligible companies selected to participate in the study were contacted by telephone to schedule a visit. During this visit interviewers conducted face-to-face interviews with the company's high management (owners, directors, supervisors, managers), totaling 58 interviews. Because it was difficult to schedule an interview with high management in some companies, an additional 23 interviews were conducted with staff designated by the management. A total of 81 companies participated in the study. All interviews were conducted between June and December 2009.

\section{Statistical analysis}

Data were double-entered and checked for consistency in Epi Info 6.0. Data were then transferred to the statistical package STATA 10.0 for analyses. Descriptive statistics were used to describe the sample as they were suitable for the study purposes.

\section{Ethical issues}

The study project was approved by the Research Ethics Committee of the School of Physical Education, Universidade Federal de Pelotas (protocol number 057/2009). All company respondents signed an informed consent form prior to the interview.

\section{RESULTS}

A total of 285 industry companies in the city of Pelotas were identified from the two selected databases (CIPEL and EBGE), of which $31.0 \%$ had 20 or more employees and were eligible to participate in the study. Refusal rate was $4.4 \%$ and losses were $8.8 \%$ (no contact or unable to schedule a visit), and therefore $13.2 \%$ of eligible companies were not included in the study. The final sample comprised 81 industry companies as follows: $44.4 \%$ food industry companies; $35.8 \%$ construction; $6.2 \%$ printing and publishing; and $13.6 \%$ from other business sectors (leather footwear, clothing, hospital medical equipment, industrial automation, tires, highway management, plastic and chemicals).

Employee demographic characteristics showed that $64.2 \%$ of the participating companies had up to 50 employees, $71.2 \%$ had up to 50 male employees and 
91.0\% had up to 50 female employees. Regarding employee functions, $76.6 \%$ of the companies had up 50 employees in the manufacturing division and $92.3 \%$ had up to 50 employees in the administrative division. Data showed that the Pelotas industry comprised mostly small businesses $(82.7 \%)$ with up to 100 employees.

Table 1 shows data on employee social environment and organization for promoting and implementing workplace physical activity (e. g., staff associations, OSHC, employee sports teams). Less than half of the companies (45.7\%) reported staff associations or OSHCs; of these, $75.7 \% \mathrm{did}$ not promote physical or other non-occupational activities either on-site or elsewhere. Employee sports teams were reported in $37.0 \%$ companies, and they were largely male teams (90.0\%).

Table 1 - Characteristics of employee social environment and organization

\begin{tabular}{lcc}
\hline Staff association or OSHC $(n=81)$ & $n$ & $\%$ \\
\hline Yes & 37 & 45.7 \\
\hline No & 44 & 54.3 \\
\hline Non-occupational physical activity promotion $(n=37)$ & & \\
\hline Yes & 09 & 24.3 \\
\hline No & 28 & 75.7 \\
\hline Employee sports teams $(n=81)$ & & \\
\hline Yes & 30 & 37.0 \\
\hline No & 51 & 73.0 \\
\hline Type of employee sports teams $(n=30)$ & & \\
\hline Male-only & 27 & 90.0 \\
\hline Male-female & 03 & 10.0 \\
\hline
\end{tabular}

$\S \mathrm{OSHC}=$ occupational safety and health committee

Fitness programs and incentives offered by the companies to promote physical activity among employees were not widely advertised (Table 2). Incentives offered by the companies including health club discounts and subsidized memberships to health clubs and gyms and employee sports teams were poorly advertised. Only $16.7 \%$ of companies reporting employee sports teams promoted and advertised them.

Table 2 - Advertisement of health club discounts, subsidized memberships to health clubs and gyms and employee sports teams.

\begin{tabular}{lcc}
\hline Subsidized memberships to health clubs/gyms $(n=13)$ & $n$ & $\%$ \\
\hline Yes & 6 & 46.2 \\
\hline No & 7 & 53.8 \\
\hline Health club discounts $(n=10)$ & & \\
\hline Yes & 00 & 00 \\
\hline No & 10 & 100 \\
\hline Employee sports teams $(n=30)$ & & \\
\hline Yes & 5 & 16.7 \\
\hline No & 25 & 83.3 \\
\hline
\end{tabular}

Table 3 presents a description of the companies' physical environments and facilities for physical activity and availability of fitness equipment. Fitness rooms and sport courts were reported in $12.4 \%$ and $9.9 \%$ of companies, respectively. Showering facilities and locker rooms were available in $91.4 \%$ of the companies and bicycle parking in $82.7 \%$. Of the 81 participating companies, fitness bicycles were 
available for employees in $14.8 \%$ and free weights and other fitness equipment in $4.0 \%$. No company reported the availability of treadmills and weight machines.

Table 3 - Description of physical environments for physical activity and fitness equipment offered by companies

\begin{tabular}{lccc}
\hline \multicolumn{1}{c}{ Items evaluated } & Availability & $\mathrm{n}$ & $\%$ \\
\hline \multirow{2}{*}{ Indoor spaces for physical activity } & Yes & 10 & 12.4 \\
\cline { 2 - 4 } Sport courts & No & 71 & 87.6 \\
\hline \multirow{2}{*}{ Showering facilities and locker rooms } & Yes & 08 & 9.9 \\
\cline { 2 - 4 } & No & 73 & 90.1 \\
\hline \multirow{2}{*}{ Bicycle parking } & Yes & 74 & 91.4 \\
\hline \multirow{2}{*}{ Weight equipment and treadmills } & No & 07 & 8.6 \\
\cline { 2 - 4 } & Yes & 67 & 82.7 \\
\hline \multirow{2}{*}{ Fitness bicycle } & No & 14 & 17.3 \\
\hline \multirow{2}{*}{ Free weights and other fitness equipment } & Yes & 0.0 & 0.0 \\
\cline { 2 - 4 } & No & 81 & 100.0 \\
\hline
\end{tabular}

\section{DISCUSSION}

Environments that promote physical activity make people more likely to have an active life; lack of spaces in which people can engage in physical activity is frequently reported as a significant barrier to a more active lifestyle. ${ }^{5,19}$ Workplaces that provide adequate physical environments can promote physical activity among employees who can have the benefits of being regularly physically active. The present study aimed to describe the opportunities for employee physical activity available in local industry companies in Pelotas. To our best knowledge this is the first study conducted in Brazil to describe physical infrastructure, availability of fitness equipment and incentives for physical activity in the industrial environment.

This study showed that companies did not provide any fitness equipment such as weight machines, fitness bicycles, treadmills and free weights to encourage employees to engage in physical activities during their working hours. A U.S. study that also assessed the workplace environment reported similar results. The Missouri Heart Disease and Stroke Prevention Program Worksite Inventory Report evaluated 251 companies for facilities and incentives for employee physical activity and found that $91.6 \%$ of companies did not offer either facilities or fitness equipment. ${ }^{13}$ It is noteworthy that U.S. data are consistent with those reported in the present study suggesting that companies do not provide facilities for employee physical activity in both high- and middle-income countries like Brazil.

Further studies are needed to produce more evidence supporting that availability of facilities/equipment can increase physical activity levels among employees and that facilitated access to them can affect employees' choices about physical activity. Larsen et al. ${ }^{20}$ reported a $24 \%$ to $46 \%$ increase in the proportion of employees exercising at least three times a week following an intervention with the provision of fitness equipment at the workplace. 
Another major factor determining employees' adoption and adherence to an active lifestyle is the availability of adequate, attractive environments for physical activity. The present study found that companies lacked structured environments. No company offered fitness rooms or spaces specifically designated for exercise and only $9.9 \%$ had sport courts in the company's physical space. This finding is corroborated by two U.S. studies. Choi et al. ${ }^{14}$ reporting that, in Georgia, of 586 companies evaluated, only $13.0 \%$ offered indoor sport courts and fitness rooms. And the Missouri Heart Disease and Stroke Prevention Program Worksite Inventory Report reported that $19.6 \%$ of 251 companies evaluated had outdoor spaces for physical activity. ${ }^{13}$

It is key to have adequate physical activity environments at companies. They need to adapt their facilities and build new spaces including sport courts, walking trails and fitness rooms so that an employee physical activity program could be developed and implemented at the workplace.

Kruger et $\mathrm{al}^{6}$ reported in the U.S. that adequate environments can promote physical activity. They found that employees who perceived the workplace as an adequate setting for physical activity were more physically active and felt encouraged to participate in health promotion programs.

Intervention actions including secure bicycle parking and showering facilities and locker rooms favored active commuting to work in high-income countries. ${ }^{21}$ Our study found that $82.7 \%$ of the companies evaluated provided bicycle parking and showering facilities and $74.0 \%$ locker rooms. It opens up a great opportunity for encouraging employee active commuting behavior. An intervention study was conducted by Vuori et al. ${ }^{21}$ with 1,256 industry workers in Finland who were provided information on the benefits of active commuting and the availability of showering facilities and locker rooms. At the end of the six-month educational intervention, $57.0 \%$ of subjects reported increased active commuting and $19.0 \%$ reported increased levels of leisure-time physical activity.

Mutrie et al..$^{22}$ conducted an intervention study aimed to promote active commuting by walking or cycling including 295 workers from three companies in Glasgow, Scotland. The educational intervention consisted of providing workers an information booklet including information on behavior change, commuting routes, personal safety, showering facilities and secure bicycle parking and a list of useful contacts combined with an activity journal, workplace map, local maps and reflective safety wear. At the end of six months, the intervention group showed a mean increase in walking to work from 52 to 79 minutes compared to an increase from 50 to 60 minutes among controls. The educational intervention was not successful in increasing commuting by cycling; the main explanation given by the authors was difficulty riding with traffic. Following a similar line of research, Gilson et al. ${ }^{23}$ performed a randomized clinical trial (10-week educational intervention) with 214 management staff from colleges in the UK, Australia and Spain. Subjects were divided into three groups: controls - instructed to keep their usual walking during the intervention; intervention group 1 - instructed to increase their daily step count following walking routes; and intervention group 2 - instructed to accumulate step counts during working tasks. At the end of the 10-week intervention the authors reported that the intervention groups increased the amount of physical activity through walking compared to the control group.

Pelotas is a city of flat topography that favors commuting by cycling. However, the city does not have bicycle infrastructure as there are few bike lanes and drivers' 
lack awareness of cyclists does not make commuting safe enough to attract a large number of commuter cyclists. A 2007 survey of the prevalence of active commuting to work in the state of Rio Grande do Sul showed that only $13.7 \%$ of women and $12.8 \%$ men actively commuted to work by walking or cycling. ${ }^{24}$ Since active commuting to work is one way people can achieve the recommended weekly levels of physical activity (150 minutes) $)^{23,25,26}$ it calls for intersectoral actions for ensuring basic infrastructure including well-marked, signposted, safe bike lanes and walking paths combined with additional facilities including secure bike parking and showering facilities and locker rooms for employees.

The social environment also plays a major role for successful promotion of healthy lifestyles among workers. In addition to negotiating with their employers to adapt and improve the company's fitness facilities and allow flexible schedules with time to do physical activity during the workday, employee associations can promote actions for recreation and increased non-occupational physical activity such as recreational tournaments, fitness classes, walking groups, competitive teams, among others. Group exercise is the preferred type of physical activity; it increases motivation for exercise and is major alternative approach to promote employee physical activity. Data from the 2004 Santa Catarina Workers' Lifestyle Report showed that $60.2 \%$ of 2,574 respondents reported a preference for group physical activities with a similar proportion among men and women $(60.7 \%$ and $59.3 \%$, respectively) ${ }^{27}$ However, data collected in the present study suggested that workers find it difficult to organize themselves in staff associations or employee committees to promote leisure-time physical or sport activities.

For successful health promotion interventions and programs must be widely advertised to all employees so that they have the knowledge to choose to participate. Educational interventions can increase both leisure-time and work physical activity $^{28}$ and increase physical activity and total energy expenditure. ${ }^{28,29}$ The present study found that physical activity programs offered by companies were not widely advertised. Only $16.7 \%$ of the companies advertised the opportunities to participate in employee sports teams, but $42.6 \%$ advertised the subsidized programs they offered to employees.

Health club discounts and subsidized memberships to health clubs and gyms are good incentives for leisure-time physical activity and offer employees an opportunity to choose the option that best meets their needs considering that clubs and gyms have been identified as preferred settings for physical activity. A study conducted with workers in the state of Santa Catarina showed that $33.2 \%$ of 2,574 respondents reported a preference for gym or health club physical activities. ${ }^{27}$

The U.S. Centers for Disease Control and Prevention together with the World Health Organization (WHO) issued a set of goals and objectives in the Healthy People $2020^{30}$ that provides five strategies to increase workplace physical activity on a population level as follows: to identify and disseminate interventions at the workplace; to encourage interaction between other industry companies to identify opportunities for physical activity promotion; to identify and educate leaderships to be healthy living promoters; to formulate and implement policies for employer-sponsored physical activity programs; and to monitor and evaluate interventions. ${ }^{30}$ However, these goals can only be accomplished through joint action of companies, government agencies and universities and others to ensure the implementation of policies for adequate physical environments and the availability of fitness rooms, sport courts, walking trails, bicycle parking, showering facilities 
with locker rooms and flexible work schedules. This investment should not be seen as a social burden, but rather as the efforts of employers to invest in their workers' health.

The Brazilian Industry Social Services (SESI) Active Leisure Program is a reference intervention in Brazil designed to promote physical activity among workers and their families. The SESI program provides health services and leisure activities to workers and their families. The participating companies offer different strategies including educational sessions and materials, presentations, workshops, motivation approaches with counseling and assessment, and incentives including promotion events, environment adaptation, workplace exercise programs and sports activities to provide workers opportunities to engage in regular physical activity. ${ }^{31}$ This intervention has reduced the prevalence of physical inactivity from $46.2 \%$ to $30.8 \%$ in the state of Santa Catarina. ${ }^{31}$

One of the main limitations of this study is that data was obtained through interviews and company facilities were not inspected. Also, as information regarding the level of physical activity among workers was not collected, we were not able to assess the relationship between workplace physical and social environments and physical activity level among industry workers in Pelotas. On the other hand, it should be noted this was the first study conducted in Brazil to specifically evaluate workplace characteristics and incentives for non-occupational physical activity among workers. The study findings could be potentially used in public policymaking for planning and developing promotion actions and incentives for active commuting to work.

\section{CONCLUSIONS}

Industry companies in the city of Pelotas did not have adequate physical environments for non-occupational physical activity. However, there are some factors including the availability of showering facilities and locker rooms that open up great opportunities to active commuting. There is a need for government's attention and commitment to invest in restructuring urban road network in Pelotas and create bike lanes and walking routes that will allow safe cycling or walking commuting to and from work.

\section{Acknowledgments}

We thank the undergraduate students of Physical Education at the Universidade Federal de Pelotas who participated in the study as interviewers and helped with data collection, the directors of the participating companies and CIPEL for allowing access to its database.

\section{Author contributions}

VVR was responsible for the study design and drafted the first version of the manuscript. PCH, AJR, GIM and MRD reviewed the manuscript. All authors reviewed and approved the final version of the manuscript.

\section{REFERENCES}

1. World Health Organization. Global status report on noncommunicable diseases 2010. Geneva - Suíça: World Health Organization; 2011.

2. Hallal PC, Andersen LB, Bull FC, Guthold R, Haskell W, Ekelund U. Global physical activity 
levels: surveillance progress, pitfalls, and prospects. Lancet 2012 21;380(9838):247-57.

3. Nahas MV. Estilo de vida e hábitos de lazer dos trabalhadores das indústrias brasileiras: relatório geral. Brasilia: SESI; 2009.

4. Del Duca GF, Oliveira ESA, Sousa TF, Silva KS, Nahas MV. Inatividade física no lazer em trabalhadores da indústria do Rio Grande do Sul, Brasil. Motriz 2011;17(1):180-8.

5. Sherwood NE, Jeffery RW. The behavioral determinants of exercise: implications for physical activity interventions. Annu Rev Nutr 2000;20:21-44.

6. Kruger J, Yore MM, Bauer DR, Kohl HW. Selected barriers and incentives for worksite health promotion services and policies. Am J Health Promot 2007;21(5):439-47.

7. Silva SG, Silva MC, Nahas MV, Viana SL. Variables associated with leisure-time physical inactivity and main barriers to exercise among industrial workers in Southern Brazil. Cad Saúde Pública, Rio de Janeiro 2011;27(2):249-59.

8. Matson-Koffman DM, Brownstein JN, Neiner JA, Greaney ML. A site-specific literature review of policy and environmental interventions that promote physical activity and nutrition for cardiovascular health: what works? Am J Health Promot 2005;19(3):167-93.

9. Engbers LH, van Poppel MN, Chin APMJ, van Mechelen W. Worksite health promotion programs with environmental changes: a systematic review. Am J Prev Med 2005;29(1):61-70.

10. Pronk NP. Physical activity promotion in business and industry: evidence, context, and recommendations for a national plan. J Phys Act Health 2009;6 (Suppl 2):S220-35.

11. UCWHP. Utah Worksites: On the Path to Corporate Wellness. Utah; 2001.

12. Oldenburg B, Sallis JF, Harris D, Owen N. Checklist of Health Promotion Environments at Worksites (CHEW): development and measurement characteristics. Am J Health Promot 2002;16(5):288-99.

13. Dietz M, Greene J. 2003 DHSS Missouri Heart Disease and Stroke Program Worksite Inventory Report. Jefferson City, Missouri, Services MDoHaS;2003.

14. Choi HS, Briker SK, Troy K, Kanny D, E. PK. Worksite Health Promotion Policies and practices in Georgia: 2002 Georgia Worksite Survey. Atlanta, GA: Georgia Department of Human Resources, Division of Public Health; 2004.

15. Shimotsu ST, French SA, Gerlach AF, Hannan PJ. Worksite environment physical activity and healthy food choices: measurement of the worksite food and physical activity environment at four metropolitan bus garages. Int J Behav Nutr Phys Act 2007;4:17.

16. Brissette I, Fisher B, Spicer DA, King L. Worksite characteristics and environmental and policy supports for cardiovascular disease prevention in New York State. Prev Chronic Dis 2008;5(2).

17. Cox MH, Miles DS. Workplace active living and total quality management: a paradigm for a new corporate culture. Quiney HA, Gauvin L, Wall AET, editors: Champaign: Human Kinetics; 1994.

18. EBGE. Cadastro Industrial. [citado 2009 mar 10]; Disponível em: http://www.ebge.com.br.

19. French SA, Story M, Jeffery RW. Environmental influences on eating and physical activity. Annu Rev Public Health 2001;22:309-35.

20. Larsen P, Simons N. Evaluating a federal health and fitness program: indicators of improving health. AAOHN J 1993;41(3):143-8.

21. Vuori IM, Oja P, Paronen O. Physically active commuting to work--testing its potential for exercise promotion. Med Sci Sports Exerc 1994;26(7):844-50.

22. Mutrie N, Carney C, Blamey A, Crawford F, Aitchison T, Whitelaw A. "Walk in to Work Out": a randomised controlled trial of a self help intervention to promote active commuting. J Epidemiol Community Health 2002;56(6):407-12.

23. Gilson ND, Puig-Ribera A, McKenna J, Brown WJ, Burton NW, Cooke CB. Do walking strategies to increase physical activity reduce reported sitting in workplaces: a randomized control trial. Int J Behav Nutr Phys Act 2009;6:43.

24. Silva SG, Del DucaI GF, Silva KS, Oliveira ESA, Nahas MV. Commuting to and from work and factors associated among industrial workers from Southern Brazil. Rev Saúde Pública 2012;46(1).

25. USDHHS. Physical Activity Guidelines Advisory Committee. Physical Activity Guidelines Advisory Committee Report, 2008. . Washington, DC: U.S. Department of Health and $\mathrm{Hu}-$ man Services; 2008.

26. Rombaldi AJ, Menezes AM, Azevedo MR, Hallal PC. Leisure-time physical activity: associa- 
tion with activity levels in other domains. J Phys Act Health 2010;7(4):460-4.

27. Nahas MV, Fonseca SA. Estilo de Vida e Hábitos de Lazer dos Trabalhadores da Indústria Catarinense (1999-2004): Relatório Geral. Florianópolis: SESI; 2004.

28. Hager RL, Hardy A, Aldana SG. Evaluation of an internet stage-based physical activity intervention. Am J Health Educ 2002;33:329-35.

29. Marshall AL, Leslie ER, Bauman AE, Marcus BH, Owen N. Print versus website physical activity programs: a randomized trial. Am J Prev Med 2003;25(2):88-94.

30. USDHHS. Healthy People 2020. Washington, DC 2013 [citado 2013 abr 19]; Disponível em: http://www.healthypeople.gov.

31. Nahas MV, Barros MVG, Oliveira ESA, Simm EE, Matos GAG. Active Leisure: A program to promote active and healthy lifestyles among industrial workers. Rev Bras Ativ Fís Saúde 2010;15(4).
Corresponding author Virgílio Viana Ramires Rua General Neto, 360 APT. 403 Centro - Pelotas/ RS - Brasil E-mail: virgilioramires@hotmail.com
Received 10/06/2012

Revised 04/30/2013

05/07/2013

Approved 05/09/2013 